\title{
Badanie dominacji półkulowej dla funkcji mowy $z$ zastosowaniem techniki rezonansu magnetycznego
}

\section{An fMRI assessment of hemispheric language dominance}

\author{
Agnieszka Pluta, Tomasz Wolak, Henryk Skarżyński \\ Instytut Fizjologii i Patologii Słuchu, Światowe Centrum Słuchu, Naukowe Centrum Obrazowania \\ Biomedycznego, Warszawa/Kajetany
}

Adres autora: Agnieszka Pluta, Światowe Centrum Słuchu, Naukowe Centrum Obrazowania Biomedycznego, ul. Mokra 17, Kajetany, 05-830 Nadarzyn, e-mail: a.pluta@ifps.org.pl

\section{Streszczenie}

Cel: Celem pracy było opracowanie procedury badawczej do określania dominacji półkulowej dla funkcji mowy z zastosowaniem metody funkcjonalnego rezonansu magnetycznego.

Materiał i metody: W badaniu wzięły udział 4 zdrowe osoby dorosłe różniące się współczynnikiem lateralizacji: 1 osoba praworęczna oraz 3 osoby leworęczne. Podczas badania techniką fMRI w skanerze 3-teslowym zastosowano zadanie fluencji słownej prezentowane w schemacie blokowym. Dominację półkulową dla funkcji mowy określano na podstawie indeksu lateralizacji, który odnosi się do liczby aktywnych wokseli w obszarach mózgu odpowiedzialnych za mowę w prawej oraz lewej półkuli mózgowej.

Wyniki: U wszystkich badanych osób uzyskano zwiększoną aktywność hemodynamiczną w regionach odpowiadających ośrodkom Broki i Wernickego. Badani różnili się w zakresie współczynnika lateralizacji LI, co wskazuje na odmienny wzorzec dominacji półkulowej dla funkcji mowy u osób różniących się preferencją w zakresie używania rąk.

Wnioski: Wyniki badania potwierdziły efektywność paradygmatu opracowanego w celu określania dominacji półkulowej dla funkcji mowy.

Słowa kluczowe: dominacja półkulowa • lateralizacja • fMRI • ręczność

Abstract

Aim of the study: Reliable assessment of language function representations in the brain is vital for neurosurgery but it has also gained importance in psychiatry as reduced laterality was found in a number of diseases. Many paradigms have been applied to investigate language: related areas but to date, no golden standard exists as to which paradigms may be effectively used. The objective of the study was to develop and assess a method to examine hemispheric dominance for language with the use of fMRI.

Material and methods: To evaluate the potential clinical usefulness of the method we examine 4 healthy adults with different value of lateralization index measured with the Edinburgh Handedness Inventory (EHI). To asses hemispheric lateralization we used the verb generation task (VGT) in which subjects were presented with a noun and asked to silently generate associated verbs. The study was performed in the 3T MAGNETOM TRIO scanner. Laterality indexes (LIs) were calculated for each participant in the ROIs corresponding to Broca's and Wernicke's areas.

Results: In all participants we found language-related activations in Broca's and Wernicke's areas. We also found different hemispheric representation of language functions in left handed and right handed participants.

Conclusions: The results of the study proved the effectiveness of the paradigm in examining language networks. This study may have important implications for diagnosing language lateralization in different populations.

Key words: hemispheric dominance $\bullet$ language lateralization $\bullet \mathrm{fMRI} \bullet$ handedness 


\section{Wstęp}

Termin asymetria półkulowa odnosi się do różnic strukturalnych oraz funkcjonalnych między półkulami mózgowymi. Wśród przejawów asymetrii funkcjonalnej szczególne miejsce zajmuje lateralizacja funkcji mowy oraz ręczność (tzn. dominacja jednej z rąk). Liczne badania z zakresu neuropsychologii (tzn. badania pacjentów z lezjami mózgu) wskazują na dominację lewej półkuli dla czynności mowy związanych z fluencją słowną, planowaniem ruchów narządów artykulacyjnych, mową wewnętrzna, zdolnością do rozróżniania dźwięków mowy, utrzymywaniem w pamięci słuchowych wzorców słów [1].

Powyższe obserwacje zostały także potwierdzone przez badania z zastosowaniem próby amytalowej (tzn. próby Wady). U ok. 96\% osób praworęcznych i ok. 70\% leworęcznych obserwuje się dominację lewej półkuli dla funkcji mowy. W przypadku ok. $4 \%$ osób praworęcznych i $15 \%$ osób leworęcznych obserwuje się odwrotny wzorzec lateralizacji [2].

Należy podkreślić, że lateralizacja nie oznacza ścisłego podziału funkcji między lewą a prawą półkulą mózgową. Większość procesów mózgowych jest realizowana poprzez współdziałania obu półkul mózgowych, a specjalizacja funkcji oznacza, że każda z półkul mózgowych kontroluje inne aspekty tych procesów (Grabowska, 2005).

Rozwój nowoczesnych metod neuroobrazowania mózgu umożliwił nieinwazyjne badania funkcji mózgowych u osób zdrowych oraz pacjentów neurologicznych (m.in. cierpiących na epilepsję lekooporną) i psychiatrycznych [3-7]. Jedną $\mathrm{z}$ najczęściej stosowanych technik pomiaru funkcji mózgowych jest technika funkcjonalnego rezonansu magnetycznego (ang. functional magnetic resonance imaging, fMRI), która dostarcza informacji o tzw. poziomie aktywności hemodynamicznej w tkance nerwowej, czyli pozwala ocenić zaangażowanie różnych struktur mózgu w wykonanie określonego zadania [8]. Najnowsze badania potwierdzają, że technika fMRI może być wykorzystywana w diagnostyce przedoperacyjnej wtedy, kiedy konieczne jest opracowanie map funkcjonalnych, czyli zlokalizowanie obszarów mózgowych zaangażowanych m.in. w funkcje motoryczne, somatosensoryczne, wzrokowe lub słuchowe. Diagnostyka oparta na wynikach uzyskanych techniką fMRI oraz obrazowaniu tensora dyfuzji (ang. diffusion tensor imaging, DTI), dostarczającej informacji o przebiegu szlaków istoty białej, może w znaczący sposób pomóc w zminimalizowaniu obszaru resekcji tak, aby ominąć obszary mózgu kluczowe dla funkcjonowania psychomotorycznego [9].

Technika fMRI jest często wykorzystywana do badań nad lateralizacją funkcji mózgowych podczas diagnostyki przedoperacyjnej, kiedy konieczne jest określenie półkuli dominującej dla mowy $[9,10]$. W praktyce klinicznej (przedoperacyjne mapowanie funkcji mowy) badacze ograniczają się zazwyczaj do lokalizacji ośrodków mowy zaangażowanych $\mathrm{w}$ generowanie oraz rozumienie mowy [11]. Do najczęściej stosowanych paradygmatów służących do pobudzenia ośrodka Broki należą - specjalnie dostosowane do specyfiki badania w skanerze MRI - zadania polegające na generowaniu słów np. rozpoczynających się na wybraną literę lub pasujących do kategorii nadrzędnej.
W przeciwieństwie do klasycznych testów fluencji słownej, pacjenci są proszeni o generowanie słów bezgłośnie, co pozwala na zminimalizowanie artefaktów związanych $\mathrm{z}$ ruchami żuchwy. Do mapowania obszarów mózgu zaangażowanych w rozumienie mowy najczęściej wykorzystuje się zadania polegające na: a) słuchaniu krótkich tekstów o charakterze narracyjnym, b) dokonywaniu decyzji syntaktycznej lub semantycznej dotyczących zdań lub słów, np. zdecyduj, czy prezentowane zwierzę pełni funkcje użytkowe w gospodarstwie domowym (krowa, wiewiórka itp.) $[3,5,12,13]$.

Następnie w celu określenia półkuli dominującej dla funkcji mowy porównuje się różnice $\mathrm{w}$ aktywności metabolicznej mózgu w obszarach odpowiadających ośrodkom Broki oraz Wernickego w prawej i lewej półkuli mózgu i oznacza się tzw. indeks lateralizacji (ang. lateralization index, LI). Jest on wyrażony za pomocą następującego równania: LI $=(\mathrm{L}-\mathrm{P}) /(\mathrm{L}+\mathrm{P})$, gdzie litery $\mathrm{P}$ i L oznaczają odpowiednio liczbę aktywnych wokseli w prawej i lewej półkuli [14].

Badania wykorzystujące metody neuroobrazowania mózgu potwierdziły wcześniejsze obserwacje dotyczące pacjentów z uszkodzonym mózgiem, wskazując na zaangażowanie wielu ośrodków mózgu (leżących poza obszarem Broki i Wernickego) w procesy językowe oraz na dużą zmienność międzyosobniczą w zakresie reprezentacji czynności mowy w mózgu. Oznacza to, że tradycyjne paradygmaty nakierowane na pobudzenie obszarów mowy jednocześnie uaktywniają inne regiony mózgu zaangażowane m.in. $\mathrm{w}$ procesy uwagowe lub pamięć roboczą [15]. Zauważono również, że w zależności od procedury badawczej oraz zmiennych międzyosobniczych (np. strategii poznawczych stosowanych do rozwiązywania zadań) uzyskiwano odmienny wzorzec pobudzenia [16].

Liczne prace dotyczące badań nad dominacją półkulową dla funkcji językowych, w których wykorzystano metodę fMRI, wskazują na zmniejszenie lateralizacji dla funkcji mowy w przypadku zaburzeń neurorozwojowych (np. zaburzeń ze spektrum autyzmu), psychiatrycznych (m.in. schizofrenii) [17], specyficznego zaburzenia rozwoju językowego (ang. specific language impairment, SLI) [13]. Także w przypadku osób lewo- lub oburęcznych częściej można się spodziewać obustronnej lub mieszanej aktywacji ośrodków mowy np. ośrodka Broki w prawej półkuli oraz ośrodka Wernickego w lewej półkuli. W przypadku osób leworęcznych oraz $\mathrm{z}$ historią leworęczności w rodzinie struktury mózgu związane z mową wykazują mniejszy stopień specjalizacji niż w przypadku osób praworęcznych. Oznacza to, że u osób leworęcznych częściej niż u praworęcznych obserwuje się obustronną lub odwróconą reprezentację dla funkcji mowy [4].

Powyższe dane wskazują na dużą przydatność techniki fMRI do mapowania funkcji językowych, lecz należy pamiętać, że ma ona znacznie większe wymagania techniczne i metodologiczne niż klasyczne badania strukturalne MR lub badania behawioralne. Czynniki, które mogą wpływać na sposób prowadzenia badań oraz interpretację wyników, zostały omówione poniżej.

Niezbędnym czynnikiem warunkującym możliwość przeprowadzenia badania jest odpowiedni poziom 
funkcjonowania poznawczego pacjenta. W przypadku pacjentów neurologicznych lub psychiatrycznych przed badaniem techniką fMRI powinna zostać przeprowadzona diagnoza neuropsychologiczna, na podstawie której można ocenić, czy stan pacjenta umożliwia jego zaangażowanie się w zadanie badawcze. W przypadku, gdy pacjent np. nie rozumie poleceń lub nie jest zmotywowany do wykonania zadania (w tym wypadku np. generowania słów), interpretacja wyników nie jest możliwa.

Koniecznym etapem badania jest również trening poza skanerem, podczas którego pacjent jest zapoznawany $\mathrm{z}$ procedurą oraz konkretnymi zadaniami prezentowanymi podczas właściwego badania w skanerze MR. Jeśli podczas sesji treningowej badacz zauważy, że pacjent nie rozumie poleceń lub zadania są dla niego za trudne, należy dostosować je do możliwości konkretnego pacjenta (czyli np. zalecane jest uproszczenie zadań prezentowanych w skanerze lub wydłużenie sesji treningowej). W przeciwnym razie interpretacja wyników jest obarczona dużym błędem. Zbyt trudny paradygmat badawczy powoduje bowiem angażowanie dodatkowych obszarów mózgu, co utrudnia określenie dominacji półkulowej.

Wśród czynników wpływających na lateralizację funkcji mózgowych wyróżnia się wiek, obecność lezji mózgu, ręczność, historię ręczności w rodzinie $[11,18,19]$. Lateralizacja funkcji poznawczych wykazuje również dynamikę w ciągu życia. U dzieci obserwuje się bardziej symetryczne mózgowe reprezentacje funkcji językowych. Asymetria wzrasta wraz z wiekiem, osiągając stały poziom między 20 a 25 rokiem życia, a następnie spada. Należy to wziąć pod uwagę podczas interpretacji danych [5]. Badania Szaflarskiego oraz współpracowników (2011) wykazały, że lewostronna dominacja półkulowa dla funkcji mowy rośnie wraz z wiekiem zarówno u osób prawo-, jak i leworęcznych. W przypadku dorosłych osób leworęcznych obserwuje się dużą zmienność indywidualną w lokalizacji pobudzeń.

Obecność guza mózgu zmienia sygnał BOLD w półkuli objętej zmianą nowotworową, co może prowadzić do błędnych decyzji dotyczących dominacji półkulowej dla badanych funkcji [19].

Kolejnym ważnym czynnikiem, który może wpływać na wynik badania, a w związku z tym na determinację dominacji półkulowej, jest wybór metody analiz oraz progu statystycznego [12]. Większość badaczy jest zgodnych, że do określenia współczynnika lateralizacji powinny być wykorzystywane woksele znajdujące się w obszarach odpowiadających za mowę, więc wybór maski (tzn. obszaru, z którego liczona jest odpowiedź hemodynamiczna) jest kluczowy $[4,14]$. Do określenia dominacji dla ośrodków Wernickego oraz Broki powinny być stosowane oddzielne paradygmaty badawcze, przeznaczone do ich funkcji.

Cytowane wyniki badań wskazują, że mimo stosunkowo dużej popularności badań techniką fMRI, nadal nie opracowano obowiązujących standardów badań klinicznych, których celem byłoby określenie reprezentacji mózgowej dla funkcji językowych. Celem pracy było opracowanie procedury badawczej do określania dominacji półkulowej dla funkcji mowy z zastosowaniem metody funkcjonalnego rezonansu magnetycznego. Paradygmat został skonstruowany w taki sposób, aby docelowo mógł służyć szerokiej grupie pacjentów diagnozowanych w Światowym Centrum Słuchu Instytutu Fizjologii i Patologii Słuchu - zarówno dzieciom, jak i osobom dorosłym.

\section{Materiał i metody}

\section{Parametry akwizycji obrazów MRI}

Badanie funkcjonalne dominacji półkulowej dla funkcji mowy zostało wykonane w Naukowym Centrum Obrazowania Biomedycznego Instytutu Fizjologii i Patologii Słuchu w Kajetanach na skanerze 3T Siemens Trio Tim. Parametry poszczególnych sekwencji były następujące: SingleShot EPI w płaszczyźnie axial o rozdzielczości anizotropowej $2 \times 2 \times 3 \mathrm{~mm}, \mathrm{TR}=3000 \mathrm{~ms}, \mathrm{TE}=30 \mathrm{~ms}$, flip angle $=90, \mathrm{FOV}=192 \times 192 \mathrm{~mm}$, matrix $64 \times 64,37$ warstw, grubość warstwy: $3 \mathrm{~mm}$.

\section{Procedura badania techniką fMRI}

Podczas badania techniką fMRI ochotnicy wykonywali zadanie językowe polegające na generowaniu w myślach czasowników pasujących do prezentowanych słuchowo rzeczowników tzn. auto - prowadzić, wyprzedzać, mama - bawić się, kochać itp. Taka procedura (bezgłośne generowanie słów) jest często stosowana w badaniach mózgowych mechanizmów mowy, ponieważ pozwala na ograniczenie artefaktów związanych z ruchami żuchwy podczas wypowiadania słów [5].

Badanie zostało przeprowadzone w schemacie blokowym. Każdy blok zadaniowy trwał 30 sekund, podczas których co $6 \mathrm{~s}$ prezentowano rzeczowniki ( 5 słów w bloku). W zadaniu kontrolnym przez 30 sekund prezentowano punkt fiksacji. Wszystkie bodźce prezentowane były słuchowo obuusznie. Do stymulacji użyto słuchawek piezoelektrycznych kompatybilnych $\mathrm{z}$ rezonansem.

\section{Osoby badane}

W badaniu wzięły udział cztery osoby dorosłe (dwie kobiety i dwóch mężczyzn), różniące się pod względem preferencji w zakresie używania rąk. Wszystkie osoby badane były w ogólnym dobrym stanie zdrowia, bez historii chorób neurologicznych i psychiatrycznych w wywiadzie. Na podstawie badania MRI wykluczono obecność malformacji ośrodkowego układu nerwowego. Ręczność została określona na podstawie Edynburskiego Kwestionariusza Lateralizacji (EHI) [20]. Charakterystyka osób badanych została przedstawiona w tabeli 1 .

\section{Opracowanie i analiza wyników badań}

Analiza danych uzyskanych w badaniu czynnościowym została przeprowadzona $\mathrm{z}$ wykorzystaniem oprogramowania SPM8 (www.fil.ion.uci.ac.uk/spm/software/spm8) $\mathrm{w}$ środowisku programu MATLAB (MathWorks, Natick, MA, USA). Przygotowanie obrazów do analizy odbyło się $\mathrm{z}$ zastosowaniem standardowych procedur składających się $\mathrm{z}$ korekcji ruchu głowy ( $\mathrm{z}$ pierwszym skanem $\mathrm{z}$ serii czasowej jako obrazem referencyjnym), normalizacji przestrzennej obrazu mózgu (na podstawie wzorca MNI programu 
Tabela 1. Charakterystyka osób badanych

Table 1. Patient characteristics

Inicjały osoby badanej

\begin{tabular}{ccccc}
\hline & \multicolumn{2}{c}{ Inicjały osoby badanej } \\
\cline { 2 - 5 } & M. J. & M. R. & A. D. & A. S. \\
\hline Płeć & K & M & K & 35 \\
\hline Wiek & 26 & 28 & 35 & wyższe \\
\hline Wykształcenie & wyższe & wyższe & -1 & -0.5 \\
\hline EHI & 1 & -1 & tak & nie \\
\hline $\begin{array}{c}\text { Historia leworęczności } \\
\text { W rodzinie }\end{array}$ & nie & nie & & \\
\hline
\end{tabular}

Tabela 2. Obszary mózgu (wraz ze współrzędnymi, wartością statystyki T oraz liczbą wokseli) o zwiększonej aktywności hemodynamicznej (T>5,16; $p<0,05$, FWE)

Table 2. The areas of increased hemodynamic response with coordinates, $T$ value and number of voxels $(T>5.16, p<0.05$, FWE)

\begin{tabular}{|c|c|c|c|c|c|}
\hline \multirow{2}{*}{ Obszar mózgu } & \multicolumn{3}{|c|}{ Koordynaty } & \multirow{2}{*}{ Wartość T } & \multirow{2}{*}{$\begin{array}{l}\text { Liczba aktywnych } \\
\text { wokseli }\end{array}$} \\
\hline & $\mathbf{x}$ & $y$ & z & & \\
\hline \multicolumn{6}{|c|}{ M. J. } \\
\hline Zakręt czołowy górny LP & 4 & 8 & 60 & 10,7 & 444 \\
\hline Zakręt czołowy środkowy LP & 48 & 2 & 48 & 10,6 & 601 \\
\hline Móżdżek & -40 & -66 & -26 & 9,37 & 170 \\
\hline Dolny zakręt czołowy LP & 60 & 18 & 10 & 8,97 & 262 \\
\hline Zakręt skroniowy górny PP & 68 & -10 & 4 & 6,9 & 63 \\
\hline Zakręt czołowy dolny PP & -52 & 8 & 28 & 6,9 & 37 \\
\hline Zakręt skroniowy górny PP & -58 & -26 & 0 & 6,6 & 21 \\
\hline Klinek LP & 28 & -90 & 31 & 6,2 & 10 \\
\hline \multicolumn{6}{|c|}{ A. D. } \\
\hline Zakręt czołowy środkowy PP & -24 & 4 & 68 & 12,7 & 1501 \\
\hline Zakręt przedśrodkowy LP & 62 & 4 & 28 & 11,2 & 396 \\
\hline Móżdżek LP & 16 & -78 & -44 & 10,7 & 4490 \\
\hline Zakręt skroniowy górny LP & 70 & -22 & 2 & 10,2 & 600 \\
\hline Płacik ciemieniowy dolny PP & -46 & -44 & 46 & 9,9 & 154 \\
\hline Zakręt czołowy środkowy & 42 & -6 & 60 & 8 & 64 \\
\hline Móżdżek PP & -6 & -80 & -42 & 7,8 & 41 \\
\hline Zakręt skroniowy środkowy PP & -60 & -56 & -6 & 7,8 & 77 \\
\hline Zakręt skroniowy górny LP & 42 & -58 & 14 & 7,8 & 23 \\
\hline Zakręt czołowy dolny LP & 56 & 34 & 10 & 7,4 & 46 \\
\hline Zakręt czołowy dolny PP & -52 & 40 & -2 & 7,2 & 20 \\
\hline Klinek & 18 & -84 & 20 & 6,1 & 15 \\
\hline Wyspa LP & 38 & 16 & 9 & 6 & 17 \\
\hline
\end{tabular}




\begin{tabular}{|c|c|c|c|c|c|}
\hline \multicolumn{6}{|c|}{ M. $R$. } \\
\hline Dodatkowe pole ruchowe & -24 & -22 & 76 & 20 & 855 \\
\hline Móżdżek LP & 40 & -62 & -26 & 15,7 & 2554 \\
\hline Zakręt skroniowy górny LP & 68 & -24 & 0 & 11,9 & 311 \\
\hline Móżdżek PP & -28 & -58 & -52 & 10,17 & 268 \\
\hline Zakręt skroniowy środkowy PP & -48 & -32 & -4 & 9,4 & 268 \\
\hline Klinek & 2 & -84 & 8 & 9,2 & 633 \\
\hline Zakręt czołowy dolny PP & -26 & 34 & -24 & 8,5 & 36 \\
\hline Płacik ciemieniowy dolny PP & -66 & -42 & 22 & 7,9 & 36 \\
\hline Zakręt czołowy górny LP & 28 & 42 & 14 & 7,7 & 30 \\
\hline Zakręt skroniowy górny PP & -52 & -34 & 12 & 7,5 & 22 \\
\hline Płacik ciemieniowy dolny LP & 58 & -40 & 28 & 7,5 & 37 \\
\hline Zakręt przedśrodkowy PP & -52 & -10 & 12 & 7,12 & 34 \\
\hline Zakręt czołowy dolny LP & 54 & 20 & -4 & 6,6 & 49 \\
\hline Zakręt czołowy dolny LP & 38 & 22 & -6 & 6,4 & 51 \\
\hline Zakręt czołowy środkowy PP & -38 & 32 & 38 & 6,4 & 28 \\
\hline Zakręt skroniowy środkowy PP & -46 & -62 & 6 & 5,9 & 24 \\
\hline Zakręt czołowy dolny LP & 46 & 14 & 28 & 5,8 & 9 \\
\hline \multicolumn{6}{|c|}{ A. $S$. } \\
\hline Móżdżek LP & 38 & -56 & -50 & 7,2 & 24 \\
\hline Móżdżek PP & -38 & -60 & -54 & 6,8 & 45 \\
\hline Zakręt przedśrodkowy LP & 60 & 4 & 10 & 6,5 & 16 \\
\hline Zakręt czołowy środkowy LP & 36 & 52 & 16 & 6,2 & 29 \\
\hline Zakręt czołowy górny PP & -38 & 36 & 36 & 5,9 & 11 \\
\hline
\end{tabular}

SPM8, rozdzielczość: $2 \times 2 \times 2 \mathrm{~mm}$ ) i przestrzennej filtracji wygładzającej (filtr gaussowski FWHM=6 mm). Do modelowania zmian sygnału BOLD zastosowano filtrację filtrem górnoprzepustowym o okresie $128 \mathrm{~s}$, a następnie metodę GLM (Uogólniony Model Liniowy) oraz standardową funkcję HRF (ang. hemodynamic response function).

Współczynnik lateralizacji wyliczano przy użyciu programu LI-toolbox [14] na podstawie porównania pobudzeń prawej i lewej półkuli w okolicach Broki oraz Wernickego. Tak wyliczony współczynnik lateralizacji przyjmuje wartości od -1 do +1, gdzie wartości większe od 0,2 są traktowane jako dominacja lewopółkulowa; wartości mniejsze od -0,2 jako dominacja prawopółkulowa, a wartości z przedziału $<-0,2 ; 0,2>-$ jako brak określonej dominacji półkulowej.

\section{Wyniki}

W przypadku wszystkich badanych uzyskano pobudzenia $\mathrm{w}$ rejonach odpowiadających ośrodkowi Broki (zakręt czołowy dolny) oraz ośrodkowi Wernickego (tylna część zakrętu skroniowego górnego). Dodatkowo aktywne były obszary mózgu zaangażowane w procesy uwagowe,
Tabela 3. Współczynniki lateralizacji uzyskane na podstawie badania techniką fMRI u poszczególnych osób Table 3. Laterality index estimated with the use of fMRI in individual subjects

\begin{tabular}{ccc}
\hline $\begin{array}{c}\text { Osoba } \\
\text { badana }\end{array}$ & $\begin{array}{c}\text { LI_ośrodek } \\
\text { Broki }\end{array}$ & $\begin{array}{c}\text { LI_ośrodek } \\
\text { Wernickego }\end{array}$ \\
\hline M. J. & 0,98 & 0,94 \\
\hline M. R. & $-0,72$ & 0,76 \\
\hline A. D. & $-0,98$ & $-0,59$ \\
\hline A. S. & 0,96 & 0,73 \\
\hline
\end{tabular}

podejmowanie decyzji, planowanie ruchów. W tabeli 2 przedstawiono obszary mózgu, w których odnotowano istotny wzrost sygnału w trakcie zadania fluencji słownej.

Porównanie liczby aktywnych wokseli w prawej i lewej półkuli mózgu w rejonach odpowiadających ośrodkowi Broki oraz Wernickego wykazało istnienie innego wzorca aktywności u badanych w zależności od wyników uzyskanych 

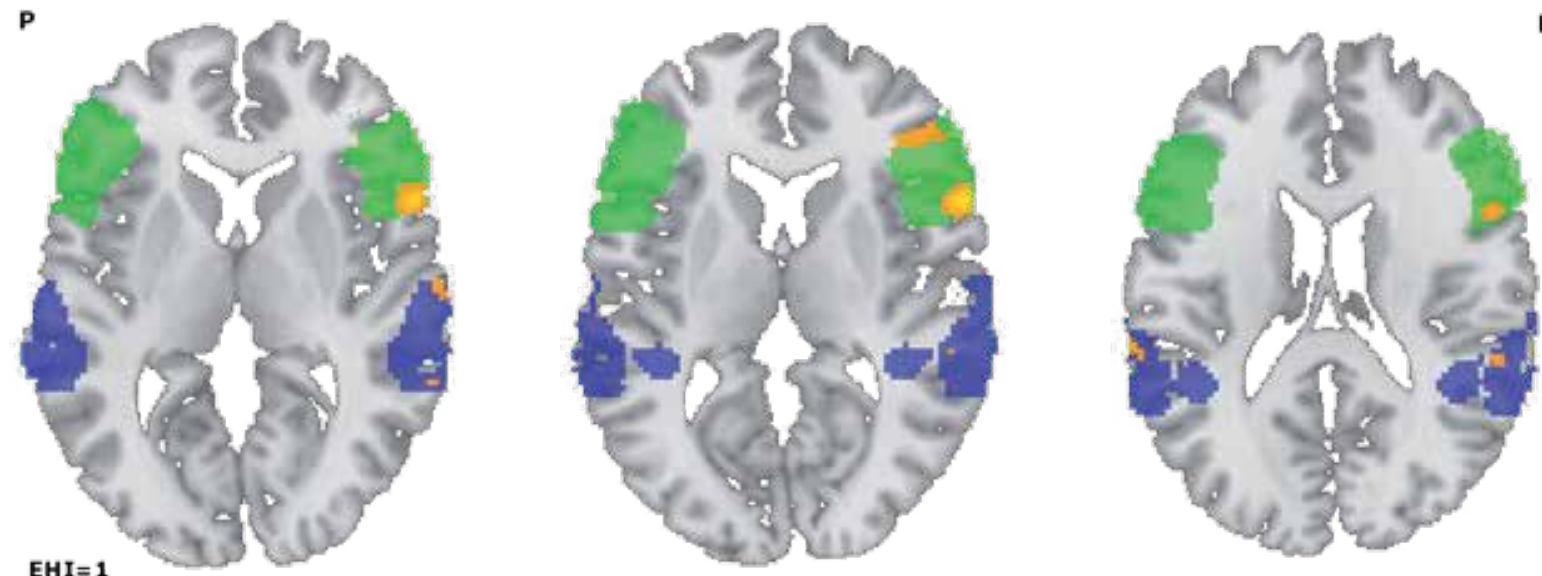

Rycina 1. Mapa aktywacji mózgu w zadaniu językowych u pacjenta M. J.

Figure 1. The map of brain activity in language paradigm in subject $M$. J.
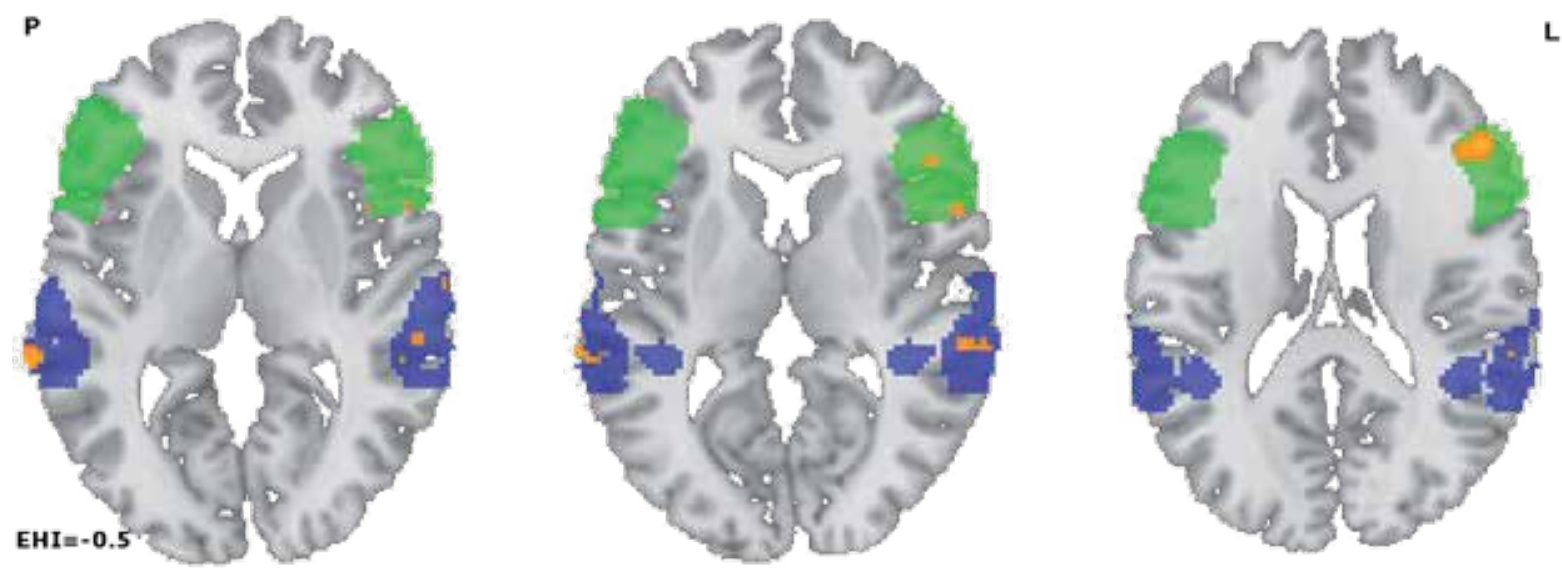

Rycina 2. Mapa aktywacji mózgu w zadaniu językowych u pacjenta A. S.

Figure 2. The map of brain activity in language paradigm in subject A. S.

w Kwestionariuszu Lateralizacji. W tabeli 3 przedstawiono wartości współczynnika lateralizacji uzyskane u poszczególnych osób badanych.

W badaniach M. J. oraz A. S. uzyskano silne pobudzenie ośrodków mowy w półkuli lewej, świadczące o dominacji lewej półkuli dla funkcji mowy (rycina 1 oraz rycina 2$).{ }^{1}$

W przypadku A. D. uzyskano silną aktywność w półkuli prawej, świadczącą o dominacji prawej półkuli dla funkcji mowy (rycina 3 ).

W przypadku M. R. uzyskano dominację lewostronną w przypadku ośrodka Wernickego, lecz prawostronną dla ośrodka Broki (rycina 4).

\section{Dyskusja}

$\mathrm{W}$ prezentowanej pracy podjęto problematykę oceny dominacji półkulowej dla funkcji mowy z zastawaniem techniki funkcjonalnego rezonansu magnetycznego. W celu pobudzenia regionów mózgu związanych $\mathrm{z}$ procesami językowymi opracowano zadanie fluencji słownej. Zostało ono dostosowane do warunków badania techniką rezonansu magnetycznego.

W badaniu wzięły udział cztery zdrowe osoby dorosłe różniące się w wynikach Edynburskiego Kwestionariusza Lateralizacji. U wszystkich badanych osób uzyskano zwiększoną aktywność hemodynamiczną w regionach odpowiadających ośrodkowi Broki i Wernickego oraz dodatkowo w obszarach zaangażowanych w procesy związane z uwagą - wyspie, płatach ciemieniowych oraz czołowych. Wzorzec aktywności jest spójny z wynikami wcześniejszych badań, w których wykorzystano zadania fluencji słownej $[4,5]$ i wskazuje, że podczas generowania słów aktywne są zarówno klasyczne obszary odpowiedzialne za procesy językowe, jak i regiony mózgu związane z procesami uwagowymi, pamięcią roboczą oraz podejmowaniem decyzji. Powyższy wynik potwierdza, że zaprezentowany

1. Wszystkie obrazy MRI przedstawione są w konwencji radiologicznej. 

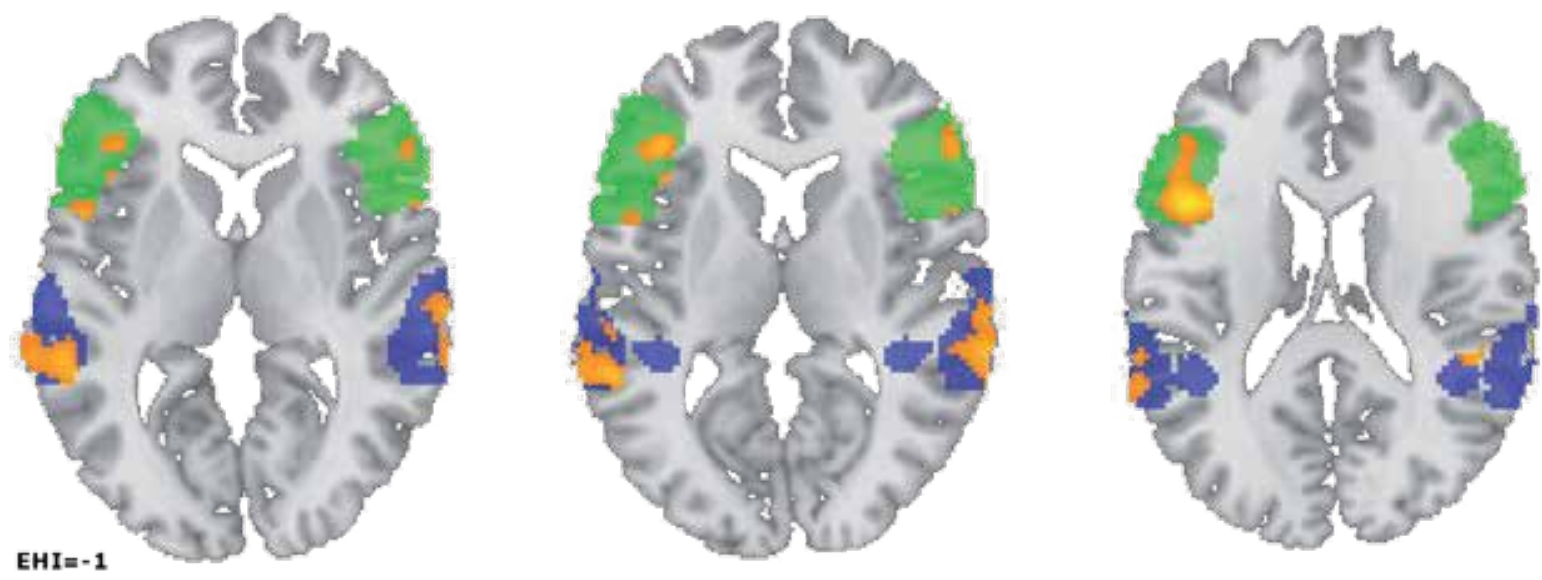

Rycina 3. Mapa aktywacji mózgu w zadaniu językowych u pacjenta A. D.

Figure 3. The map of brain activity in language paradigm in subject A. D.
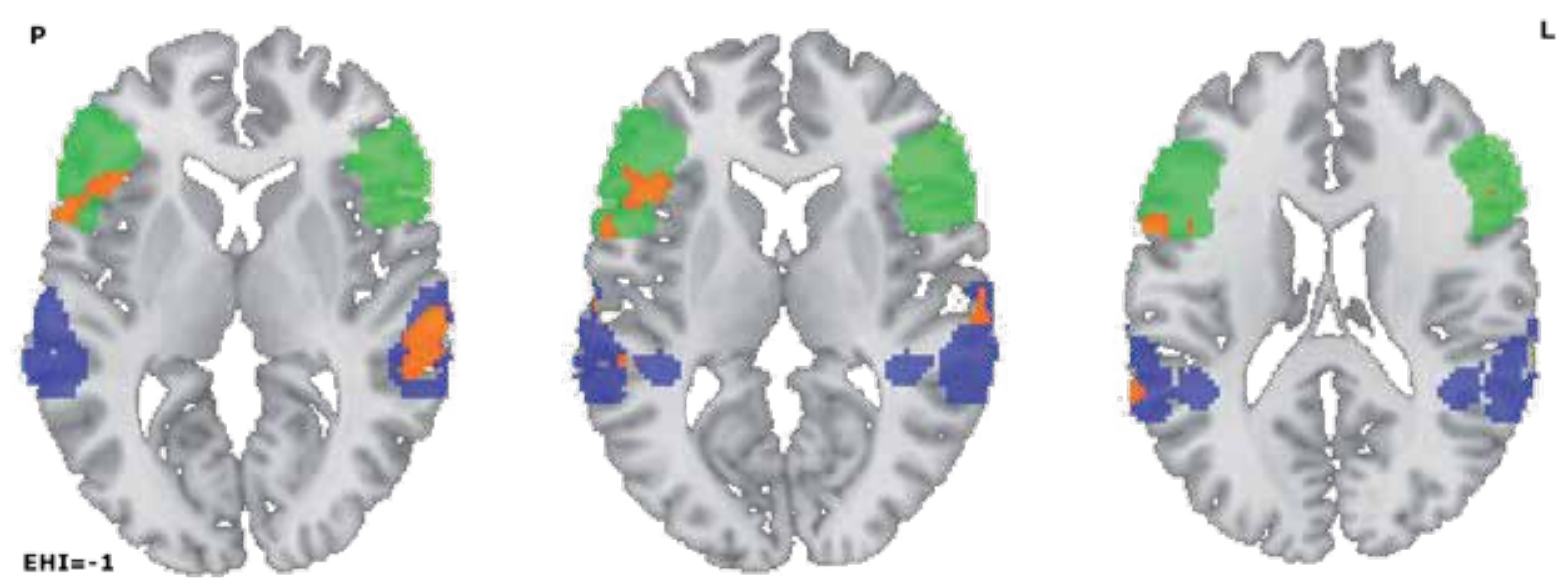

Rycina 4. Mapa aktywacji mózgu w zadaniu językowych u pacjenta M. R.

Figure 4. The map of brain activity in language paradigm in subject $M$. R.

paradygmat może być stosowany do badania funkcji językowych z wykorzystaniem techniki fMRI.

Badani różnili się w zakresie współczynnika lateralizacji LI, co wskazuje na odmienny wzorzec dominacji półkulowej dla funkcji mowy. Wyniki badania potwierdzają wcześniejsze doniesienia świadczące o braku korelacji między ręcznością a dominacją półkulową dla funkcji mowy, szczególnie w przypadku osób leworęcznych lub o nieoznaczonej ręczności [5]. Prawostronną dominację dla funkcji mowy zaobserwowano jedynie u osoby silnie leworęcznej (badana A. D.), z historią leworęczności w rodzinie. W przypadku pozostałych osób leworęcznych bez leworęczności w rodzinie zaobserwowano typową lateralizację lewostronną dla funkcji mowy (A. S.) oraz lateralizację skrzyżowaną, tzn. dominację lewej półkuli w przypadku ośrodka Wernickego oraz prawej w przypadku ośrodka Broki. Ze względu na małą liczbę zbadanych osób wyniki dotyczące wzorca dominacji półkulowej nie mogą być generalizowane na populację, lecz widoczny jest podobny trend jak w przypadku innych badań grupowych. Zgodnie $\mathrm{z}$ nim u osób praworęcznych półkulą dominującą dla mowy jest najczęściej półkula lewa, u osób leworęcznych lub o nieoznaczonej ręczności częściej zdarza się (w porównaniu z osobami praworęcznymi), że półkulą dominującą dla mowy jest półkula prawa lub że podczas generowania mowy aktywność mózgu jest obserwowana w dolnym płacie czołowym obustronnie [6].

W kontekście prezentowanego badania warto podkreślić, że kliniczne próby badania funkcji mowy za pomocą fMRI pokazują jedynie wąski zakres procesów uruchamianych podczas mówienia, czytania lub słuchania mowy. Podyktowane jest to zazwyczaj nadrzędnym celem badania, którym jest określenie, która półkula jest dominująca dla generowania lub rozumienia mowy. Dla potrzeb badania klinicznego są tworzone proste paradygmaty, które mogą być stosowane u szerokiej grupy pacjentów dorosłych lub dzieci. Mimo stosunkowo dużej powtarzalności wyników badań fMRI, badacze wciąż borykają się z wieloma problemami typu:

- brak kontroli nad tym, co dzieje się w zadaniu eksperymentalnym lub kontrolnym (spontaniczna aktywność poznawcza pacjenta podczas zadania kontrolnego 
będzie prowadziła do zwiększonej aktywności neuronalnej $\mathrm{w}$ regionach mózgu niezwiązanych $\mathrm{z}$ procesami językowymi),

- wybór konkretnej metody wyznaczania współczynnika lateralizacji (LI),

- różnice międzyosobnicze w zakresie strategii wykonywania zadań, co wpływa na aktywność neuronalną,

- trudności w zakresie wykonania zadania wynikające z braku motywacji, niedostatecznego zaangażowania procesów pamięciowych lub uwagowych [16].

\section{Wnioski}

Uzyskane wyniki wykazały, że opracowany paradygmat badawczy może być efektywnie stosowany do badania dominacji półkulowej dla funkcji mowy z zastosowaniem techniki funkcjonalnego rezonansu magnetycznego. W zależności od współczynnika lateralizacji obliczonego na podstawie badania behawioralnego oraz historii leworęczności w rodzinie uzyskano odmienny wzorzec aktywności neuronalnej w obszarach mózgu odpowiedzialnych za mowę.

Badania finansowane $z$ grantu Narodowego Centrum Nauki nr 2011/01/N/NZ4/04985.

\section{Piśmiennictwo:}

1. Bruneau EG, Pluta A, Saxe R. Distinct roles of the "shared pain" and "theory of mind" networks in processing others' emotional suffering. Neuropsychologia, 2012; 50: 219-31.

2. Bernal B, Ardila A. Bilateral representation of language: A critical review and analysis of some unusual cases. J Neurolinguistics, 2014; 28: 63-80.

3. Gupta SS. fMRI for mapping language networks in neurosurgical cases. Indian J Radiol Imaging, 2014; 24: 37-43.

4. Szaflarski JP, Binder JR, Possing ET, McKiernan KA, Ward BD, Hammeke TA. Language lateralization in left-handed and ambidextrous people: fMRI data. Neurology, 2002; 59: 238-44.

5. Szaflarski JP, Holland SK, Schmithorst VJ, Byars AW. An fMRI study of language lateralization in children and adults. Hum Brain Mapp, 2006; 27: 202-12.

6. Fernandes MA, Smith ML, Logan W, Crawley A, McAndrews MP. Comparing language lateralization determined by dichotic listening and fMRI activation in frontal and temporal lobes in children with epilepsy. Brain Lang, 2006; 96: 106-14.

7. Orringer DA, Vago DR, Colby AJ. Clinical applications and future directions of functional MRI. Seminars in Neurology, 2012; 32: 466-75.

8. Ogawa S, Lee TM, Kay AR, Tank DW. Brain magnetic resonance imaging with contrast dependent on blood oxygenation. Proc Natl Acad Sci USA, 1990; 87: 9868-72.

9. Binder JR. FMRI is a valid noninvasive alternative to Wada testing. Epilepsy Behav, 2011; 20: 214-22.

10. Janecek JK, Swanson SJ, Sabsevitz DS, Hammeke TA, Raghavan M, Mueller W, Binder JR. Naming outcome prediction in patients with discordant wada and fMRI language lateralization. Epilepsy Behav, 2013; 27: 399-403.

11. Baciu M, Kahane P, Minotti L, Charnallet A, David D, Le Bas JF, Segebarth C. Functional MRI assessment of the hemispheric predominance for language in epileptic patients using a simple rhyme detection task. Epileptic Disord, 200; 3: 117-24.
12. Dodoo-Schittko F, Rosengarth K, Doenitz C, Greenlee MW. Assessing language dominance with functional MRI: The role of control tasks and statistical analysis. Neuropsychologia, 2012; 50: 2684-91.

13. Guibert $C$ de, Maumet $C$, Jannin $P$, Ferré J-C, Tréguier $C$, Barillot $\mathrm{C}$ i wsp. Abnormal functional lateralization and activity of language brain areas in typical specific language impairment (developmental dysphasia). Brain, 2011; 134: 3044-58.

14. Wilke M, Lidzba K. LI-tool: a new toolbox to assess lateralization in functional MR-data. J Neurosci Methods, 2007; 163: $128-36$.

15. Kollndorfer K, Furtner J, Krajnik J, Prayer D, Schöpf V. Attention shifts the language network reflecting paradigm presentation. Front Hum Neurosci, 2013; 7: 809.

16. Zacà $\mathrm{D}$, Jarso $\mathrm{S}$, Pillai JJ. Role of semantic paradigms for optimization of language mapping in clinical FMRI studies. Am J Neuroradiol, 2013; 34: 1966-71.

17. Van Veelen NMJ, Vink M, Ramsey NF, Sommer IEC, van Buuren M, Hoogendam JM, Kahn RS. Reduced language lateralization in first-episode medication-naive schizophrenia. Schizophrenia Research, 2011; 127: 195-201.

18. Tzourio-Mazoyer N, Petit L, Razafimandimby A, Crivello F, Zago L, Jobard G i wsp. Left hemisphere lateralization for language in right-handers is controlled in part by familial sinistrality, manual preference strength, and head size. J Neurosci, 2010; 30: 13314-8.

19. Wellmer J, Weber B, Urbach H, Reul J, Fernandez G, Elger CE. Cerebral lesions can impair fMRI-based language lateralization. Epilepsia (Series 4), 2009; 50: 2213-24.

20. Oldfield RC. The assessment and analysis of handedness: The Edinburgh inventory. Neuropsychologia, 1971; 9: 97-113. 